\title{
An exclusion mechanism is epistatic to an internal detoxification mechanism in aluminum resistance in Arabidopsis
}

\author{
Yuqi Wang ${ }^{1,2}$, Wancong Yu ${ }^{2,3}$, Yu Cao ${ }^{2,4}$, Yanfei Cai ${ }^{2,4}$, Sangbom M. Lyi ${ }^{2}$, Weiwei Wü ${ }^{2,4}$, Yan Kang ${ }^{2,5}$,
} Cuiyue Liang ${ }^{2,4}$ and Jiping Liu ${ }^{2 *}$

\begin{abstract}
Background: In Arabidopsis, the aluminum (Al) exclusion mechanism is mainly facilitated by ALMT1-mediated malate exudation and MATE-mediated citrate releases from the root. Recently, we have demonstrated that coordinated functioning between an ALMT1-mediated Al exclusion mechanism, via exudation of malate from the root tip, and a NIP1;2-facilitated internal detoxification mechanism, via removal of Al from the root cell wall and subsequent root-to-shoot Al translocation, plays critical roles in achieving overall Al resistance. However, the genetic relationship between ALMT1 and NIP1;2 in these processes remained unclear.

Results: Through genetic and physiological analyses, we demonstrate that unlike ALMT1 and MATE, which function independently and additively, ALMT1 and NIP1;2 show an epistatic relationship in Al resistance. These results indicate that ALMT1 and NIP1;2 function in the same biochemical pathway, whereas ALMT1 and MATE in different ones.

Conclusion: The establishment of the epistatic relationship and the coordinated functioning between the ALMT1 and NIP1;2-mediated exclusion and internal detoxification mechanisms are pivotal for achieving overall Al resistance in the non-accumulating Arabidopsis plant. We discuss and emphasize the indispensable roles of the root cell wall for the implementation of the Al exclusion mechanism and for the establishment of an epistatic relationship between the ALMT1-mediated exclusion mechanism and the NIP1;2-facilitated internal detoxification mechanism.
\end{abstract}

Keywords: ALMT1, Epistasis, Malate, NIP1;2, Organic acid, Resistance mechanism, Root cell wall

\section{Background}

Aluminum (Al) is the most abundant metal element in the earth crust [1]. Under neutral or alkalescent conditions, $\mathrm{Al}$ is present in the soil as forms that are non-toxic to plants [2]. However, at low $\mathrm{pH}(<5.0)$, aluminum ions $\left(\mathrm{Al}^{3+}\right)$ are dissolved and released from the soil clays into the soil solutions, which could interact with multiple sites of the plant root cell, including the cell wall, cell membrane and cytosol with toxic effects, resulting severe root

\footnotetext{
* Correspondence: j1233@cornell.edu

${ }^{2}$ Robert Holley Center, US Department of Agriculture, Agricultural Research Service, Cornell University, Ithaca, NY 14853, USA

Full list of author information is available at the end of the article
}

growth inhibition, the most significant symptom of Al toxicity $[1,3]$. The impaired root system restricts root absorption of water and nutrients from the acid subsoil, leading to drought stresses and nutrient deficiencies and thus reduced yields for crops grown on acidic soils [1, 4].

Physiologic studies have indicated that the root apex, rather than the root elongation zone and the mature root region, is a major target of Al toxicity [5]. Cell wall loosening and synthesis of cell wall components are essential for sustained root cell elongation and water uptake [6, 7]. However, $\mathrm{Al}^{3+}$ ions severely inhibit root elongation through reducing cell wall cation binding, water permeability and cell wall enzyme activities [8-11]. As a result,

(C) The Author(s). 2020 Open Access This article is licensed under a Creative Commons Attribution 4.0 International License, which permits use, sharing, adaptation, distribution and reproduction in any medium or format, as long as you give appropriate credit to the original author(s) and the source, provide a link to the Creative Commons licence, and indicate if changes were made. The images or other third party material in this article are included in the article's Creative Commons licence, unless indicated otherwise in a credit line to the material. If material is not included in the article's Creative Commons licence and your intended use is not permitted by statutory regulation or exceeds the permitted use, you will need to obtain permission directly from the copyright holder. To view a copy of this licence, visit http://creativecommons.org/licenses/by/4.0/. The Creative Commons Public Domain Dedication waiver (http://creativecommons.org/publicdomain/zero/1.0/) applies to the data made available in this article, unless otherwise stated in a credit line to the data. 
the root cell wall in the root apical region is one of the major targets for $\mathrm{Al}$ toxicity $[12,13]$.

Plants have adopted several strategies to cope with $\mathrm{Al}$ stresses, including $\mathrm{Al}$ exclusion and internal detoxification mechanisms $[14,15]$. The exclusion mechanism relies on root releases of chemical exudates, including organic acids [16], phenolic compounds [17], and phosphate [18], which facilitates the formation of non-toxic Al-exudate complexes in the rhizosphere and thereby prevents $\mathrm{Al}$ from entering the root cell, including the root apoplast [19]. Aluminum exclusion via release of organic-acid anions, including malate, citrate and oxalate, from the root apex is the best characterized, the most effective and widespread resistance mechanism employed by a large number of monocots and dicots plants [16, 20-28]. Recently, Al- and salicylic acid (SA)activated root exudation of benzoxazinoids has been recognized as an important exclusion mechanism for $\mathrm{Al}$ resistance in Maize [29].

The internal tolerance mechanism facilitates the detoxification of $\mathrm{Al}^{3+}$ internally [30]. The processes include chelation of $\mathrm{Al}$ by organic acids in the cytosol, $\mathrm{Al}$ compartmentation in the vacuole of the root cell, translocation from sensitive root tissues to less sensitive shoot tissues where it is further sequestrated into the vacuoles of shoot cells [30-32]. However, functional and regulatory components underlying these processes remain largely unclear.

In Arabidopsis thaliana, the exclusion mechanism plays a key role in $\mathrm{Al}$ resistance $[24,25]$, which mainly relies on $\mathrm{Al}$-activated root exudation of malate and citrate via the plasma membrane (PM)-localized malate transporter, ALMT1, and the citrate transporter MATE from the multidrug and toxic compound extrusion family, respectively $[24,25]$. ALMT1 facilitates the exudation of a large amount of malate from the root tip, while MATE mediates the release of a smaller amount of citrate from the more mature root region upon $\mathrm{Al}$ exposure [26]. The expression of both ALMT1 and MATE is under the control of a master transcription factor, STOP1, i.e., sensitive to proton rhizotoxicity 1 , which plays key roles in regulation of resistance to proton (low $\mathrm{pH}$ ) and $\mathrm{Al}$ toxicity in plants $[25,33,34]$.

In Arabidopsis, $\mathrm{Al}^{3+}$ ions in the rhizosphere can freely move and be retained in the root cell wall at low $\mathrm{pH}(<$ 5.0) [19]. The $\mathrm{Al}^{3+}$ ions in the root cell wall directly or indirectly activate the PM-localized malate and citrate transporters, leading to organic acid releases from the cytosol of the root cell and formation of Al-organic acid complexes in the rhizosphere as well as in the root cell wall. Although it has been demonstrated that $\mathrm{Al}$-organic acid complexes in the rhizosphere cannot enter the root cell, including the root cell wall [19], whether the Alorganic acid complexes retained in the root cell wall are toxic to the plant remained unclear previously.
Our recent studies have demonstrated that the Arabidopsis nodulin 26-like intrinsic protein 1;2 (NIP1;2) gene encodes a PM-localized transporter that specifically transports $\mathrm{Al}$-malate (Al-Mal) complexes but not charged $\mathrm{Al}^{3+}$ ions or other forms of Al-ligand complexes from the root cell wall into the root symplast $[19,35]$. As the transport substrate of NIP1;2 is the Al-Mal complex but not the $\mathrm{Al}^{3+}$ ion, the ALMT1-mediated malate release into the root cell wall is a prerequisite for the NIP1;2-facilitated removal of $\mathrm{Al}$ from the root cell wall and subsequent translocation from the sensitive root tissues to the less sensitive shoot tissues [19]. Thus, the coordinated activities between the exclusion mechanism facilitated by ALMT1mediated malate releases and the NIP1;2-mediated internal detoxification mechanism are essential for achieving overall $\mathrm{Al}$ tolerance in Arabidopsis [19, 35].

In genetics, the terms dominant and recessive are used to describe the effects of different alleles at a genetic locus on determining the expression of a trait. Dominant alleles (AA) ultimately determine the expression of the trait, whereas recessive alleles (aa) are much less likely to be expressed. When a dominant allele is paired with a recessive one $(\mathrm{Aa})$, the dominant allele $(\mathrm{A})$ determines the trait. Recessive traits only manifest when both alleles in the locus are recessive in an individual (aa). In contrast, the term of epistasis is used to describe interactions between genes located in different genetic loci (e.g., A and B). It is referred to as a situation where the allelic actions of one locus (i.e., $\mathrm{AA}, \mathrm{Aa}$, or aa) mask the allelic effects of another locus (i.e., $\mathrm{BB}, \mathrm{Bb}$ and $\mathrm{bb}$ ), in the same way where the dominant allele mask the effects of the recessive one at the same locus [36, 37]. In other words, epistasis describe a situation where the phenotypic expression at one locus depends on the genotype of a different locus.

Here, we provide further genetic evidence for the existence of an epistatic relationship between ALMT1 and NIP1;2. We demonstrate that such an epistatic relationship is required for orchestrating the functions of different $\mathrm{Al}$ resistance mechanisms in Arabidopsis. We emphasize the essential role of the root cell wall in establishing the epistatic relationship between the ALMT1-mediated exclusion mechanism and the NIP1;2-facilitated internal detoxification mechanism in Arabidopsis. We also discuss possible relationships between the exclusion and the internal detoxification mechanisms for $\mathrm{Al}$ accumulating plants under $\mathrm{Al}$ stresses.

\section{Results}

\section{Generation of an amlt1_nip1;2 double mutant line}

Three independent T-DNA insertion mutants of NIP1;2, i.e., nip1;2-1 (SALK_126593), nip1;2-2 (SALK_147353) and nip1;2-3 (SALK_076128), displayed comparable hypersensitive phenotypes to $\mathrm{Al}$ stresses at $\mathrm{pH} 4.3$ (Additional file 1: Figure S1) [19]. To further study the 
functional and genetic relationships between NIP1;2 and ALMT1, a homozygous almt1_nip1;2 double mutant line was generated through a cross between almt1 (SALK_ 009629) and nip1;2-3 (hereafter nip1;2), followed by selection from the F2 population of mutant plants with homozygous almt1 and nip 1;2 alleles.

Real-time reverse transcription-quantitative polymerase chain reaction (RT-qPCR) analyses indicated that in the wild type (WT, Col-0), the expression of ALMT1 and $N I P 1 ; 2$ in the root was both induced by Al treatment although the levels of ALMT1 transcripts were about 4-fold higher than those of NIP1;2 (Fig. 1). Under the nip1;2 mutant background, the level of ALMT1 expression in the root was comparable with that in the WT (Fig. 1a), whereas NIP1;2 expression was greatly suppressed (Fig. 1b). In contrast, under the almt1 background, although the level of the NIP1;2 expression in the root were comparable with that in the WT, the Alinduced ALMT1 expression in the root was barely detectable (Fig. 1a). These results confirmed that both almt1 and nip1;2 are knockout (KO) mutants [19, 24] and the expression of ALMT1 and NIP1;2 is independent

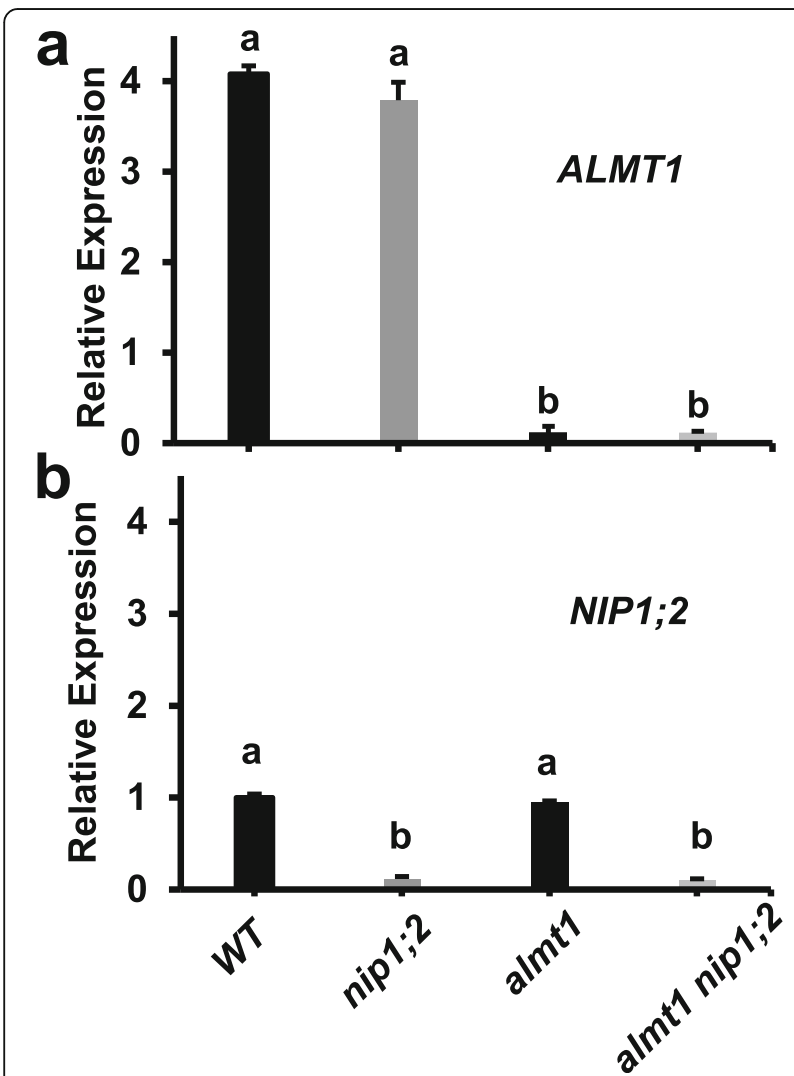

Fig. 1 Expression patterns of $A L M T 1$ (a) and $N I P 1 ; 2$ (b) in the root. Roots of 7-day-old seedlings of WT, almt1, nip 1;2 and almt1_nip 1;2 treated with $20 \mu \mathrm{M} \mathrm{AlCl}_{3}(\mathrm{pH}$ 4.3) for $24 \mathrm{~h}$ were subject to RT-qPCR analysis. Data are means \pm s.d. $(n=3)$; Different letters indicate significant differences between individual lines of each other [35]. Under the almt1_nip1;2 background, the expression of ALMT1 and NIP1;2 in the root was both barely detectable (Fig. 1a, b), indicating that almt1_ nip1;2 is a double $\mathrm{KO}$ mutant line.

\section{Comparable sensitivity between almt1_nip 1;2 and almt1 to Al stresses}

To evaluate $\mathrm{Al}$ resistance of individual lines, relative root growth (RRG\%) was calculated for 5-day-old plants of WT, nip1;2, almt1 and almt1_nip1;2 treated with a range of $\mathrm{Al}$ concentrations $(0-50 \mu \mathrm{M})$ at $\mathrm{pH} 4.3$ (Fig. 2). Root growth of both the almt1 and nip1;2 single mutants was more severely inhibited by Al than was the WT over the range of $\mathrm{Al}$ concentrations tested (Fig. 2). Moreover, root growth was more strongly inhibited in almt1 than in nip1;2 (Fig. 2). For instance, at $\mathrm{Al}$ concentration of $20 \mu \mathrm{M}$, root growth was inhibited by 82 and 69\% in almt1 and nip1;2, respectively (Fig. 2 and Additional file 1: Figure S2).

In contrast, no significant differences in root growth were observed between the almt1_nip1;2 double mutant and the almt1 single mutant over the entire range of $\mathrm{Al}$ concentrations tested (Fig. 2). Therefore, the Al-resistant phenotype of almt1_nip1;2 resembled that of almt1, but not nip1;2.

Genetic analysis of allelic effects of ALMT1 and NIP1;2 on Al resistance

To evaluate the effects of genotypic variations at the ALMT1 and NIP1;2 loci on Al resistance, a homozygous

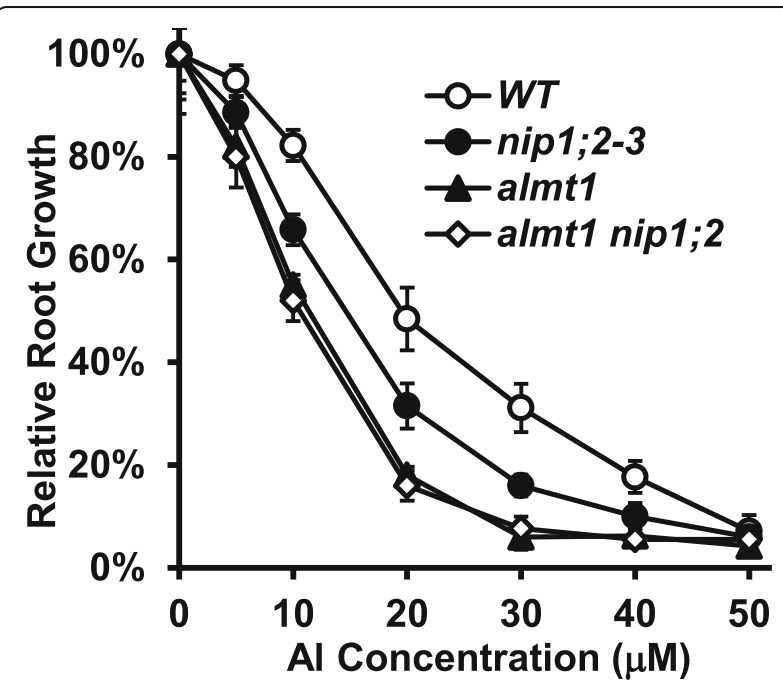

Fig. 2 Relative root growth of WT and almt1, nip 1;2 and almt1_nip 1;2 mutants. Seeds were germinated and grown in hydroponic solution ( $\mathrm{pH}$ 4.3) supplemented with 0, 5, 10, 20, 30, 40, $50 \mu \mathrm{M}$ of $\mathrm{AlCl}_{3}$ for 5 days. Root length $(\mathrm{mm})$ of individual seedlings was measured. Relative root growth (RRG\%) was calculated according to the following formula: RRG\% = root growth of individual plants under Al treatment/mean root growth under the control (-Al) condition. Data are means \pm s.d. $(n=10)$ 
almt1 plant was crossed with a homozygous nip1;2 plant to generate heterozygous $\mathrm{F} 1$ plants. The dominant and recessive alleles of ALMT1 and NIP1;2 would be segregated among the F2 plants.

Root growth was measured for F2 seedlings germinated and grown for 7 days in a hydroponic growth solution (pH 4.3) supplemented with $20 \mu \mathrm{M} \mathrm{AlCl}$. Based on their root growth, the F2 plants could be classified into three phenotypic groups (A, B and C) that showed significant differences in root growth $(\mathrm{mm})$ under $\mathrm{Al}$ treatment (Table 1 and Additional file 1: Figure S3). On the other hand, based on their allelic variations at the ALMT1 and NIP1;2 loci, the F2 population could be classified into nine distinct genotypic groups/combinations (Table 1 and Additional file 1: Figure S3).

Analysis of the relationship between phenotypic and genotypic variations indicated that 1) the F2 plants in the phenotypic group A had at least one dominant wildtype allele at both the ALMT1 and NIP1;2 loci (Table 1 and Additional file 1: Figure S3); 2) group B had homozygous almt1/almt1 alleles regardless of the status of the NIP1;2 alleles; and 3) group C had homozygous nip1;2/ nip1;2 mutant alleles and at least one wild-type allele of ALMT1, i.e., almt1/ALMT1 or ALMT1/ALMT1.

In phenotypic group $\mathrm{A}$, plants with at least one wild-type ALMT1 allele and one wild-type NIP1;2 allele had comparable root growth under $\mathrm{Al}$ treatment as those with a wildtype background, i.e., ALMT1/ALMT1 NIP1;2/NIP1;2 (Table 1 and Additional file 1: Figure S3). In contrast, homozygous almt1 and/or nip1;2 plants in phenotypic groups B and C were more sensitive to $\mathrm{Al}$ compared with the plants in group A (Table 1 and Additional file 1: Figure S3). These results indicated that the wild-type alleles of ALMT1 and NIP1;2 were both completely dominant.

Although homozygous mutations of almt1 or nip1;2 caused significant root growth inhibition (Fig. 2 and Table 1 ), the effects of genotypic variation at one locus on the phenotypic expression of the other locus were quite different between ALMT1 and NIP1;2 (Table 1). For instance, under a homozygous almt1/almt1 background (group B, Table 1), root growth was solely determined by the homozygous almt1 mutant alleles regardless of the genotypic

Table 1 Allelic effects of ALMT1 and NIP1;2 on Al resistance

\begin{tabular}{llll}
\hline Genotypes at the & \multicolumn{3}{l}{ Genotypes at the $\mathbf{N I P 1 ; 2}$ locus } \\
\cline { 2 - 4 } ALMT1 locus & nip1;2/nip1;2 & nip1;2/NIP1;2 & NIP1;2/NIP1;2 \\
\hline almt1/almt1 & $2.9 \pm 0.5^{\mathbf{B}}$ & $2.7 \pm 0.9^{\mathbf{B}}$ & $3.1 \pm 0.7^{\mathbf{B}}$ \\
almt1/ALMT1 & $6.3 \pm 1.4^{\mathbf{C}}$ & $12.1 \pm 2.4^{\mathbf{A}}$ & $10.9 \pm 1.6^{\mathbf{A}}$ \\
ALMT1/ALMT1 & $6.8 \pm 1.8^{\mathbf{C}}$ & $11.7 \pm 1.9^{\mathbf{A}}$ & $11.5 \pm 2.8^{\mathbf{A}}$ \\
\hline
\end{tabular}

Seeds were germinated and grown in hydroponic growth medium supplemented with $20 \mu \mathrm{M} \mathrm{AICl}(\mathrm{pH}$ 4.3) for 7 days. Data are mean root length $(\mathrm{mm}) \pm$ s.d. $(n=10)$. Letters represent groups with significant differences in root length $(P \leq 0.05)$ as determined by Fisher's least significant difference (LSD) test. variation at the NIP1;2 locus (Table 1 and Additional file 1: Figure S3). In contrast, under a homozygous nip1;2/ nip1;2 background, the degrees of root growth inhibition by $\mathrm{Al}$ were strongly affected by the genotypic variation at the ALMT1 locus. For instance, plants with homozygous almt1/almt1 alleles, i.e., the almt1_nip1;2 double mutant plants, displayed greatly enhanced root-growth inhibition compared with those with one or two copies of the wildtype ALMT1 allele in group C (Table 1 and Additional file 1: Figure S3). The fact that the homozygous almt1 mutation at the ALMT1 locus could mask/override the effects of genotypic variation at the NIP1;2 locus indicates that there exist interactions between the ALMT1 and NIP1;2 loci where $A L M T 1$ is genetically epistatic to NIP1;2.

\section{Additive effects of ALMT1 and MATE and epistatic relationship between $A L M T 1$ and NIP1;2 in Al resistance}

In Arabidopsis, the Al-activated and ALMT1-facilated malate exudation from the root-tip region plays a major role in $\mathrm{Al}$ resistance, while the $\mathrm{Al}$-activated and MATEmediated citrate release from more mature root regions plays a smaller but significant role [24-26]. Although both the almt1 and mate single mutants were more sensitive to a range of $\mathrm{Al}$ concentrations $(0-50 \mu \mathrm{M})$ tested than was the WT, almt1 consistently displayed significantly stronger root-growth inhibition than did the mate mutant (Fig. 3a and Additional file 1: Figure S2).

Compared with the almt1 and mate single mutants, the almt1_mate double mutant showed significantly more severe root-growth inhibition phenotypes over the entire range of $\mathrm{Al}$ concentrations tested (Fig. 3a and Additional file 1: Figure S2). For instance, at $20 \mu \mathrm{M} \mathrm{Al}$, root growth of almt1_mate was inhibited by $93 \%$, whereas root growth of almt1 and mate by 82 and $72 \%$, respectively (Fig. 3a). Thus, the effects of ALMT1 and $M A T E$ on $\mathrm{Al}$ resistance are additive, suggesting that ALMT1 and MATE function in different biochemical pathways, which is consistent with our previous observation that ALMT1 and MATE function independently in achieving overall Al resistance in Arabidopsis [25].

In contrast, the almt1_nip1;2 double mutant did not display stronger mutant phenotypes than did the almt1 single mutant (Fig. 2). Instead, root growth was comparable between almt1 and almt1_nip1;2 over the entire range of $\mathrm{Al}$ concentrations tested (Fig. 2).

\section{ALMT1-mediated root exudation of malate is independent of NIP1;2 function}

To evaluate the effects of different genotypes on root organic acid exudation, Al-activated root exudation of malate and citrate was examined for WT, almt1, nip 1;2 and almt1_nip1;2. Under the control condition (-Al), comparable basal levels of root exudation of malate and citrate were observed among individual lines (Fig. 4a, b). 


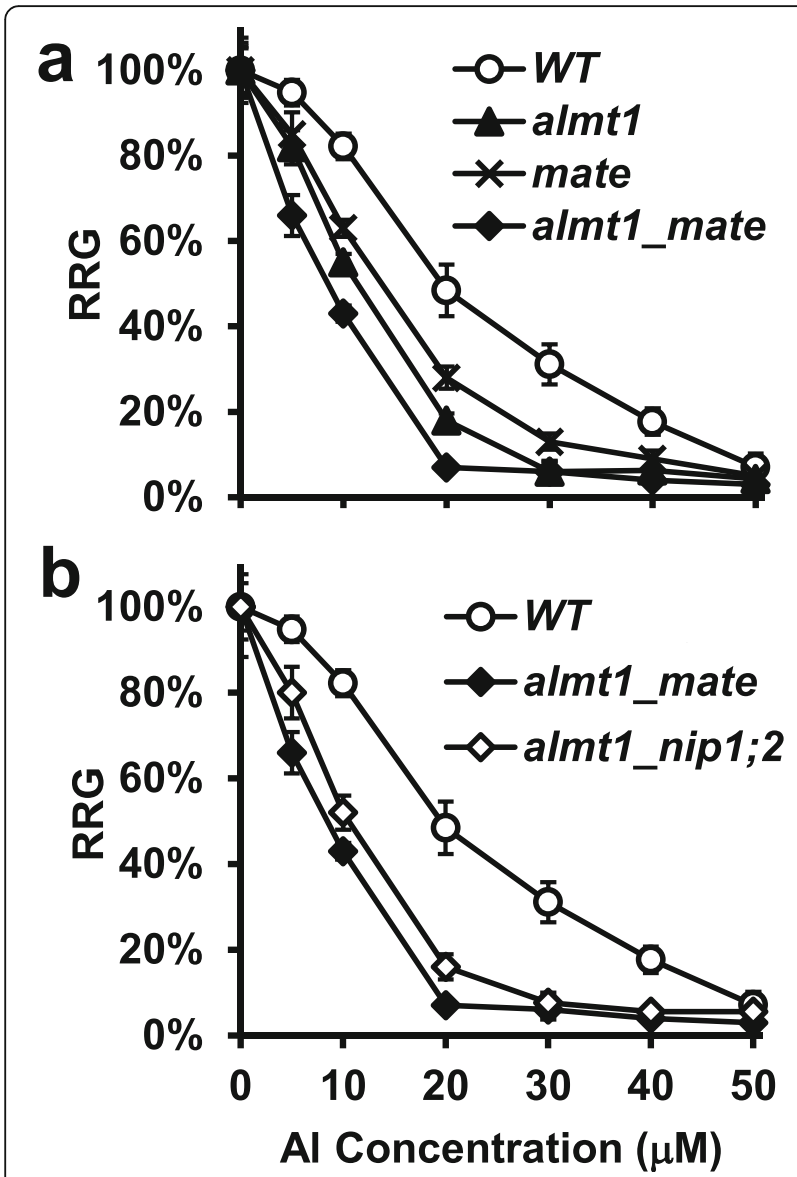

Fig. 3 Relative root growth (RRG\%) of WT and almt1, mate and almt1_mate mutants (a) and WT and almt1_mate, almt1_nip1;2 double mutants (b). Seeds were germinated and grown in hydroponic solution ( $\mathrm{pH}$ 4.3) supplemented with $0,5,10,20,30,40$, $50 \mu \mathrm{M}$ of $\mathrm{AlCl}_{3}$ for 5 days. Data are means \pm s.d. $(n=10)$

$\mathrm{Al}$ exposure triggered releases of large and comparable amounts of malate from the roots of WT and the nip 1;2 mutant (Fig. 4a). In contrast, both almt1 and almt1_ nip1;2 lacked detectable $\mathrm{Al}$-activated root malate exudation (Fig. 4a). These results indicate that Al-activated malate exudation from the root is mainly facilitated by the ALMT1 malate transporter in Arabidopsis and the $\mathrm{Al}$-activated and ALMT1-mediated root malate exudation is independent of the NIP1;2 function.

Compared with root malate exudation, $\mathrm{Al}$ exposure also triggered smaller, but significant, increases in citrate exudation from the root (Fig. 4b). In contrast, no significant differences were observed in the amounts of citrate in the root exudates from all lines examined upon $\mathrm{Al}$ exposure (Fig. 4b). These results indicate that the $\mathrm{Al}$-activated and MATE-facilitated root citrate exudation is independent of the ALMT1 and NIP1;2 functions in Arabidopsis (Fig. 4b). Thus, the phenotypes of organic acid exudation of the almt1_nip1;2 double $\mathrm{KO}$ line resemble those of the almt1 mutant, but not the nip1;2 mutant.
ALMT1 functions upstream of NIP1;2 in the process of Al removal from the root cell wall

To test the relationship between ALMT1 and NIP1;2 in the processes of $\mathrm{Al}$ removal from the root cell wall, $\mathrm{Al}$ contents in the root cell wall and cell sap were measured for the WT, almt1, nip1;2 and almt1_nip1;2 plants treated with $50 \mu \mathrm{M} \mathrm{AlCl}_{3}$ at pH 4.3 for $2 \mathrm{~d}$ (Fig. 5). Compared with the WT plants, the almt1 and nip1;2 plants accumulated significantly higher and lower concentrations of $\mathrm{Al}$ in the root cell walls (Fig. 5a) and root cell sap (Fig. 5b), respectively. These results confirmed that both ALMT1-mediated malate releases and a functional NIP1;2 are required for $\mathrm{Al}$ removal from the root cell wall into the root cytosol [19]. However, the almt1 mutant also accumulated significantly higher and lower concentrations of $\mathrm{Al}$ in the root cell wall (Fig. 5a) and the root cell sap (Fig. 5b), respectively, compared with the nip1;2 mutant. These results suggest that ALMT1-

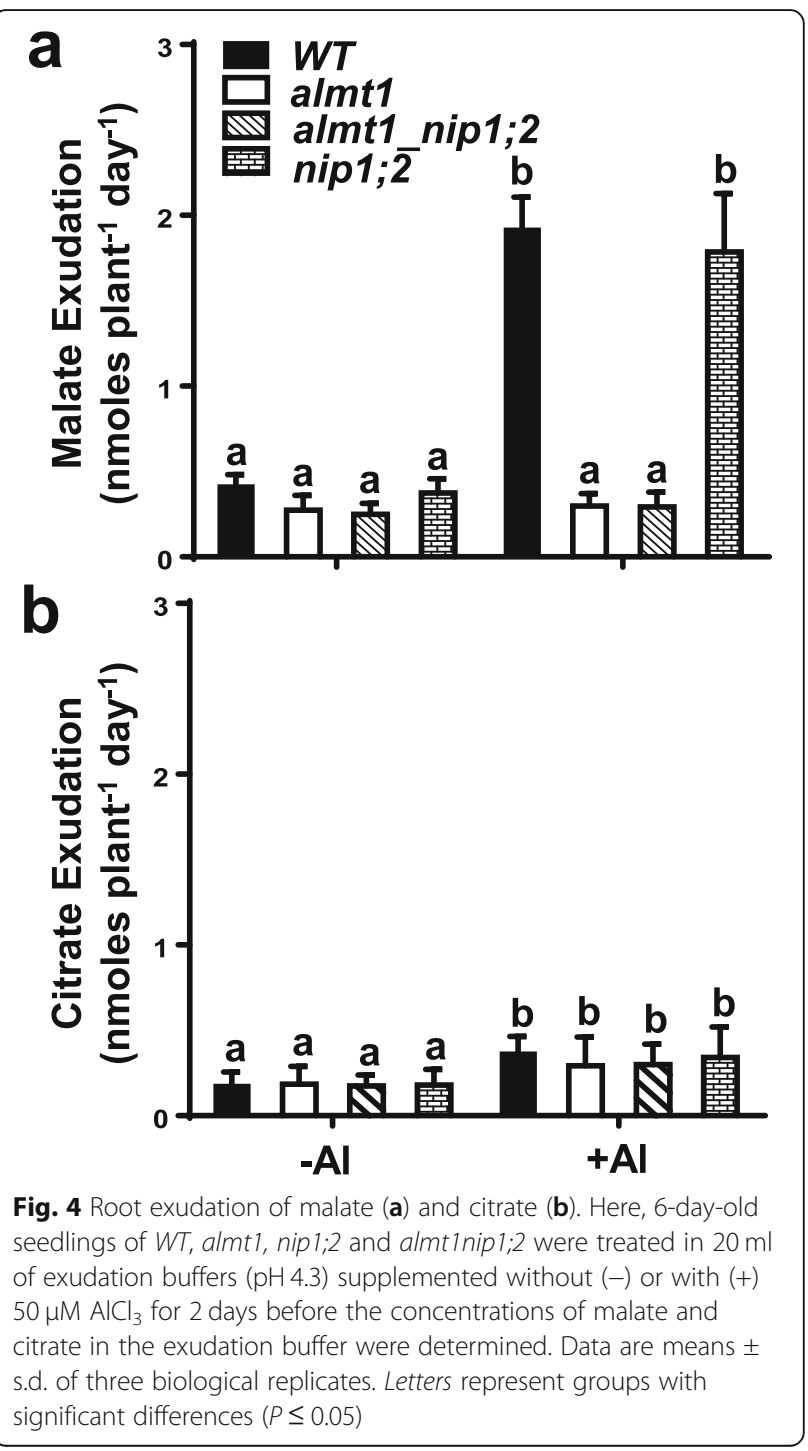




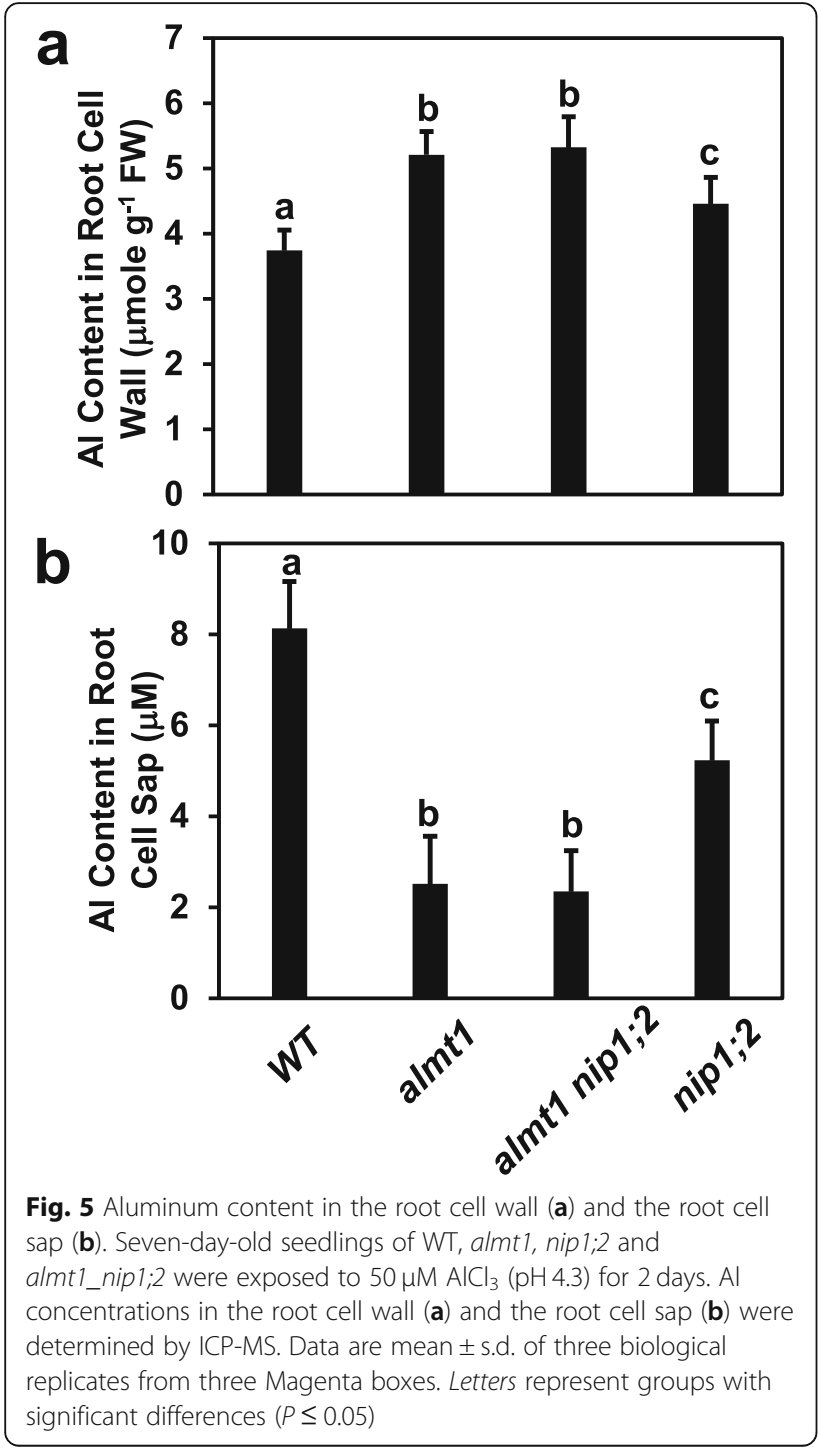

depenedent but NIP1;2-indenpent processes are present for $\mathrm{Al}$ removal from the root cell wall in Arabidopsis.

The $\mathrm{Al}$ concentrations in the root cell wall (Fig. 5a) and root cell sap of the almt1_nip1;2 double mutant (Fig. 5b) were comparable with those of the almt1 single mutant, which were significantly different from those in the nip1;2 single mutant. These results indicate that ALMT1 is genetically epistatic to NIP1;2 in the biochemical pathway leading to $\mathrm{Al}$ removal from the root cell wall into the root symplasm in Arabidopsis.

Externally supplied malate partially restored NIP1;2facilitated Al uptakes from the root cell wall in almt 1 but not in almt1_nip 1;2

To evaluate the effects of externally supplied malate on $\mathrm{Al}$ uptakes from the root cell wall for almt1, nip1;2 and almt1_nip1;2, plants were treated with $50 \mu \mathrm{M} \mathrm{AlCl}_{3}(\mathrm{pH}$ 4.3) for $8 \mathrm{~h}$, allowing $\mathrm{Al}$ to get into and be retained in the root cell walls (Fig. 6a) [19], followed by addition of 0 or $200 \mu \mathrm{M}$ malate for another $8 \mathrm{~h}$.

Between these two treatments, no statistically significant differences in $\mathrm{Al}$ contents in the root cell wall (Fig. 6a) and the root cell sap (Fig. 6b) were observed in the nip1;2 single mutant and the almt1_nip1;2 double mutant. In contrast, in almt1, compared with those under the $\mathrm{Al}$ treatment alone, external supplementation of malate after $\mathrm{Al}$ treatment led to significantly decreased $\mathrm{Al}$ concentrations in the root cell wall (Fig. 6a) and significantly increased concentrations in the root cell sap (Fig. 6b). These results indicate that even though the almt1 mutant has a functional NIP1;2 transporter [19], the presence of malate in the root cell wall is essential for NIP1;2-facilitated $\mathrm{Al}$ removals from the root cell wall. Thus, the ALMT1-mediated releases of malate to the root cell wall function in an earlier step in the NIP1;

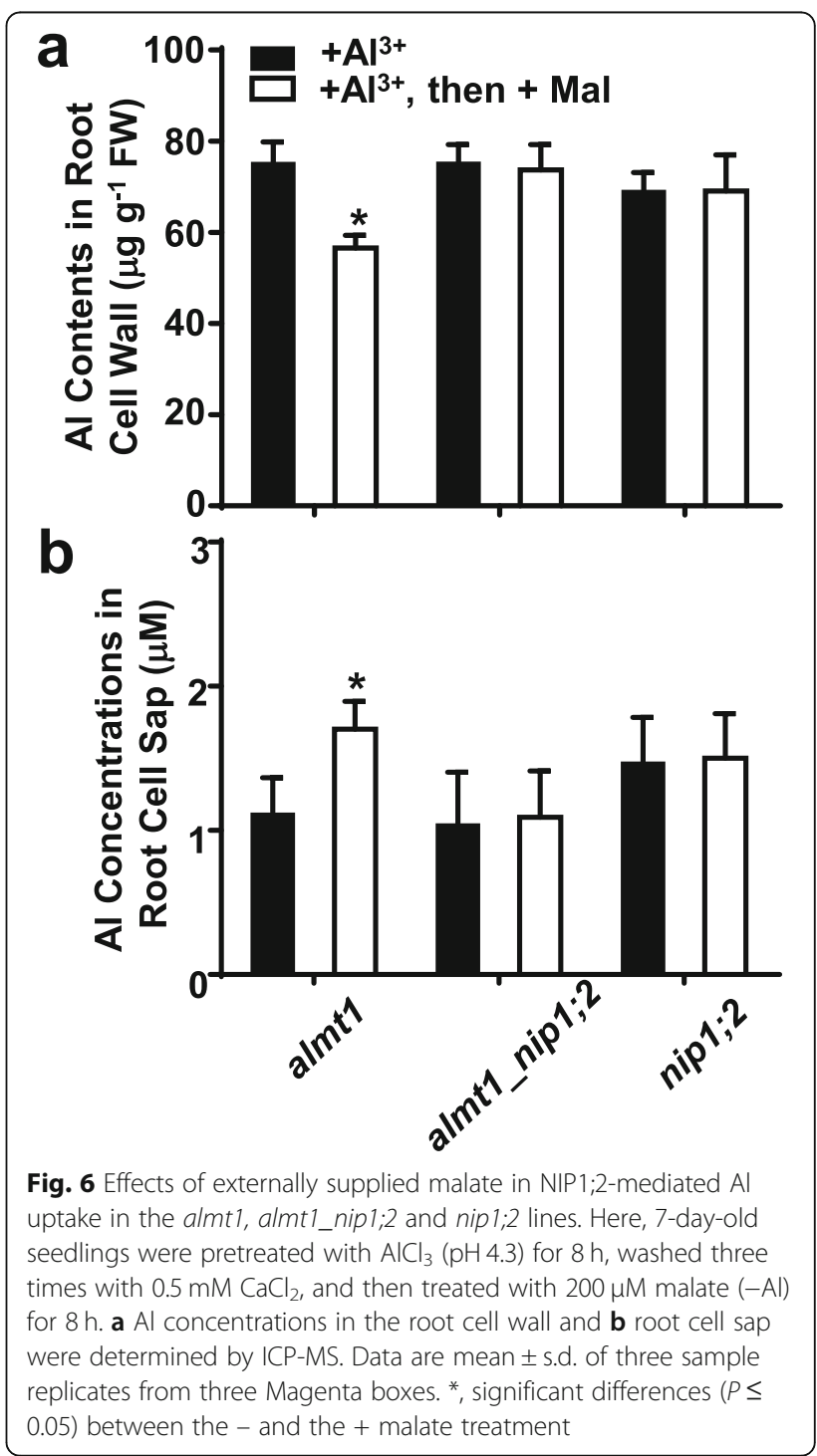


2-facilitated process for $\mathrm{Al}$ uptakes from the root cell wall to the root cytosol.

\section{Discussion}

\section{ALMT1 is genetically and functionally epistatic to NIP1;2}

In Arabidopsis, coordinated activity of ALMT1 and NIP1;2 is required for NIP1;2-facilitated Al removal from the root cell wall into the root symplasm and subsequent root-to-shoot $\mathrm{Al}$ translocation, which are critical steps in the internal detoxification mechanism [19, 32, 35]. In this process, first, the $\mathrm{Al}^{3+}$ ions enter the root apoplast from the rhizosphere and then activate the PMlocalized ALMT1 transporter, leading to malate exudation from the root tip cell into the root apoplast and rhizosphere [24-26]. In the root apoplast, the released malate interacts with the $\mathrm{Al}^{3+}$ ions to form Al-Mal complexes, which are subsequently transported from the root cell wall into the root cytosol by the PM-localized NIP1;2 [19]. As NIP1;2 transports the Al-Mal complex, but not the $\mathrm{Al}^{3+}$ ion, the ALMT1-mediated malate exudation into the root cell wall is required for the formation of Al-Mal complexes in the root apoplast and the subsequent NIP1;2-facilitated Al removal from the root cell wall (Fig. 5) [19]. Thus, ALMT1 plays a key role in both the exclusion mechanism, via facilitating malate exudation to the rhizosphere to chelate toxic $\mathrm{Al}^{3+}$ ions, and the internal detoxification mechanism, through facilitating the NIP1;2-mediated removal of the Al-Mal complex from the root cell wall and translocation from the root to the shoot [19].

Phenotypic examination of root growth indicated that the almt1_mate double mutant was more sensitive to $\mathrm{Al}$ than was either of the almt1 or mate single mutants, indicating that the effects of almt1 and mate mutations are additive (Fig. 3a). In contrast, no additive or synergistic effects were observed between the almt1 and nip1; 2 mutations (Fig. 2 and Additional file 1: Figure S1). Therefore, our root-growth experimental conditions could distinguish the additive effect of ALMT1 and MATE from the epistatic relationship between ALMT1 and NIP1;2. Further examination of Al-activated root organic-acid exudation (Fig. 4) and NIP1;2-facilitated Al removal from the root cell wall (Fig. 5) also indicated that the phenotypes of the almt1_nip1;2 double $\mathrm{KO}$ mutant resembled those of almt1, but not nip1;2. Moreover, externally supplied malate could partially compensate the loss of the ALMT1-mediated malate exudation for the NIP1;2-facilitated function in the almt1 mutant (Fig. 6). Taken together, these results indicate that ALMT1 and NIP1;2 function in a single biochemical pathway, where ALMT1 functions upstream of NIP1;2. The fact that the almt1 mutant is more sensitive to $\mathrm{Al}$ toxicity than was the nip1;2 mutant (Fig. 2) also indicates that
ALMT1 plays a larger role in contribution to overall $\mathrm{Al}$ resistance than does NIP1;2 in Arabidopsis.

\section{The significance of the epistatic relationship between ALMT1 and NIP1;2 in Al tolerance for the non- accumulating Arabidopsis}

On acid soils, most plants, i.e., the so-called nonaccumulators, limit the uptake of $\mathrm{Al}$ from the soil and accumulate no more than $0.2 \mathrm{mg} \mathrm{Al} \mathrm{g}^{-1}$ dry weight of the plant [32]. In contrast, a few $\mathrm{Al}$ accumulator plant species can accumulate much higher concentrations of $\mathrm{Al}$ in the shoot/leaf. For instance, hydrangea (Hydrangea macrophylla) plants can accumulate up to $3 \mathrm{mg} \mathrm{Al} \mathrm{g}^{-1}$ dry weight of the plant [32], while buckwheat (Fagopyrum esculentum) plants $1.7 \mathrm{mg} \mathrm{Al} \mathrm{g}^{-1}$ dry weight without showing any sings of toxicity $[38,39]$.

In both the accumulating and non-accumulating plant species, overall $\mathrm{Al}$ resistance can be achieved by the exclusion and the internal tolerance mechanisms [15, 32, 40]. However, these two mechanisms are not mutually exclusive but they are coordinately functioned as in the case of the ALMT1- and NIP1;2-mediated Al tolerance in Arabidopsis [19, 35].

Arabidopsis is a non-accumulating species for Al. Therefore, $\mathrm{Al}$ tolerance in Arabidopsis is mainly dependent on the exclusion mechanism via the ALMT1- and MATEmediated root exudation of malate and citrate, respectively, to the rhizosphere and the root apoplast where organic acids chelate the $\mathrm{Al}^{3+}$ ions [24-26]. As ALMT1 facilitates the release of a large amount of malate from the root tip region [26], a major target for Al toxicity [12, 13, 41, 42], ALMT1 makes a significantly larger contribution to overall $\mathrm{Al}$ resistance in Arabidopsis than MATE $[25,26]$.

In the root apoplast, the released malate anions chelate the $\mathrm{Al}^{3+}$ cations and thus reduce the concentration of free $\mathrm{Al}^{3+}$ cations, which minimizes the harmful interactions of these cations in the cell wall. However, the simple binding of $\mathrm{Al}$ and malate in the apoplast of the root cell is not enough to provide full protection against $\mathrm{Al}$ toxicity [19]. Instead, the Al-Mal complexes in the root apoplast need to be removed for achieving higher degrees of Al tolerance [19].

Here, we further demonstrate that ALMT1 is genetically and functionally epistatic to NIP1;2. Such an epistatic relationship allows the Arabidopsis plant to be protected by the exclusion mechanism first, which effectively blocks the entry of toxic $\mathrm{Al}^{3+}$ cations into the root cell, including the root cell wall, before the NIP1;2facilitated internal detoxification mechanism, i.e., uptakes of $\mathrm{Al}$ from the root cell wall, starts to function. Without the establishment of such an epistatic relationship between the exclusion and internal detoxification mechanisms, high levels of $\mathrm{Al}$ could be accumulated in 
the plant, which is harmful to the non-accumulator like Arabidopsis.

Therefore, for the non-accumulating plant species, a dominant exclusion mechanism is essential for $\mathrm{Al}$ resistance via continuously preventing the entry of $\mathrm{Al}$ to the root cell. After the exclusion mechanism is established, the internal detoxification mechanism will step in and play a secondary and scavenging role for removing the toxic $\mathrm{Al}^{3+}$ ions from the root apoplast and cytosol for further sequestration into the vacuole of the root cell and/or for translocation from the root to less sensitive shoot.

In contrast, for the accumulating plants to take up large amounts of $\mathrm{Al}^{3+}$ ions from the root and accumulate them in the shoot, the exclusion mechanism must be suppressed. Interestingly, $\mathrm{Al}$-activated release of oxalic acid is required for the protection of root growth and function for young seedlings of buckwheat, an $\mathrm{Al}$ accumulator, under $\mathrm{Al}$ stresses [43]. Thus, it is likely that at the early developmental stage, the exclusion mechanism is also essential for $\mathrm{Al}$ accumulators to withstand the initial shocks of $\mathrm{Al}$ toxicity. Once the internal detoxification mechanism is established at later developmental stages, the exclusion mechanism will be suppressed or discontinued to function, allowing the accumulation of large amounts of $\mathrm{Al}$ in the shoot via the internal detoxification mechanism.

\section{Essential roles of the root cell wall in overall Al resistance in Arabidopsis}

As mentioned above, the significance of the epistatic relationship between the exclusion and internal detoxification mechanisms in Arabidopsis lies in that the ALMT1mediated exclusion mechanism provides a shield/barrier for the root against the toxic $\mathrm{Al}^{3+}$ ions in the rhizosphere before the NIP1;2-facilitated internal detoxification mechanism is allowed to function. However, the pivotal roles of the root cell wall are less well recognized in this system.

The root cell wall is highly negatively charged and as a result, $\mathrm{Al}^{3+}$ cations in the rhizosphere can freely enter and be retained in the root apoplast at low $\mathrm{pH}(<5.0)$ [19]. The Al-activated and ALMT1-mediated malate release to the rhizosphere results in the formation of $\mathrm{Al}$ Mal complexes in the rhizosphere. As the Al-Mal complex is unable to enter the root cell wall [19], with a functional ALMT1-mediated malate exudation to the rhizosphere, it is the root cell wall that acts as a shield/ barrier that separates the $\mathrm{Al}$ in the rhizosphere from the root symplasm. Furthermore, the presence of such a shield ensures that only the Al-Mal complex in the root cell wall, but not in the rhizosphere, is accessible to the NIP1;2 transporter localized to the PM of the root cell. In conclusion, the root cell wall plays pivotal roles in the establishment of the exclusion mechanism as well as the epistatic relationship between the exclusion and the internal detoxification mechanisms for overall $\mathrm{Al}$ resistance and for the prevention of over-accumulation of $\mathrm{Al}$ in Arabidopsis plants.

\section{Conclusion}

Here, we demonstrate that ALMT1 is genetically epistatic to NIP1;2 for achieving coordinated functions between an exclusion and an internal tolerance mechanism and overall $\mathrm{Al}$ resistance in the non-accumulating Arabidopsis plant. This elegant system ensures that an exclusion mechanism is established before an internal tolerance mechanism steps in to achieve overall $\mathrm{Al}$ resistance in the non-accumulating Arabidopsis. The root cell wall plays indispensable roles in implementation of the $\mathrm{Al}$ exclusion mechanism and the establishment of an epistatic relationship between the ALMT1-mediated exclusion mechanism and the NIP1;2-facilitated internal detoxification mechanism. These findings further expand our knowledge about how overall $\mathrm{Al}$ resistance is achieved in plants.

\section{Methods}

\section{Materials and culture conditions}

Arabidopsis T-DNA insertion lines nip1;2-1 (SALK 126593), nip1;2-2 (SALK_147353), nip1;2-3 (SALK_ 076128), mate (SALK_081671) and almt1 (SALK 009629C) as well as WT (Col-0; CS60006) were acquired from the Arabidopsis Biological Resource Center (https://abrc.osu.edu/). The almt1_nip1;2 double mutant was generated by crossing almt1 and nip1;2-3 (nip1;2) single mutants, followed by selection of F2 plants with homozygous T-DNA insertions at both the ALMT1 and NIP1;2 loci by PCR-based genotyping [19]. The almt1_ mate double mutant was generated previously [25].

Primer sequences for genotyping the ALMT1 locus were 5' -CGCAGCTGCACATATATCACA-3' (ALMT1 gene specific primer) and $5^{\prime}$-GCTGTTGCCCGTCT CACTGGTG-3' (T-DNA left border primer) for detection of the T-DNA insertion; and 5'-CGCAGCTGCA CATATATCACA-3' and 5'-CGAAGTGCAACGCA CCACTA-3' for amplification of the sequence encompassing the T-DNA insertion region. Primer sequences for genotyping the NIP1;2 locus for nip1;2-3 were $5^{\prime}$ GCTCGCATCTAGATCCTAAT-3' (NIP1;2 gene specific primer) and 5'-GCTGTTGCCCGTCTCACT GGTG-3' (T-DNA left border primer) for detection of the T-DNA insertion; 5' - GCTCGCATCTAGATCCTA AT-3' and 5'-CGAAGTGCAACGCACCACTA-3' for amplification of the sequence encompassing the T-DNA insertion region. The positions of the T-DNA insertions as well as the primers listed above were depicted in Additional file 1: Figure S4. 
The PCR mixture $(25 \mu \mathrm{L})$ contains the following reagents: 100 ng gDNA template, $1 \mathrm{X}$ Green GoTaq ${ }^{\circ}$ Reaction Buffer (1.5 mM $\mathrm{MgCl}_{2}$ ) (Promega), $0.2 \mathrm{mM}$ each dNTP, $0.5 \mu \mathrm{M}$ upstream primer, $0.5 \mu \mathrm{M}$ downstream primer, GoTaq DNA polymerase (Promega). The PCR reactions were conducted with a T100 Thermal Cycler (BioRad) with the following thermal cycling conditions: 1 cycle of $95^{\circ} \mathrm{C}$ for $2 \mathrm{~min}$; 25 cycles of $95^{\circ} \mathrm{C}$ for $1 \mathrm{~min}$, $55^{\circ} \mathrm{C}$ for $1 \mathrm{~min}$, and $72^{\circ} \mathrm{C}$ for $2 \mathrm{~min}$; final extension at $72^{\circ} \mathrm{C}$ for $5 \mathrm{~min}$.

For growth experiments, seeds of the wild type, individual mutant lines or the F2 population from the cross of almt1 and nip1;2 were surface-sterilized and cold stratified at $4{ }^{\circ} \mathrm{C}$ in the dark for 3 days for synchronization of germination. Seeds were subsequently sown onto a $250 \mu \mathrm{M}$ polypropylene mesh in a Magenta box containing a hydroponic growth solution, supplemented with $2.0 \mathrm{mM}$ Homo-PIPES to maintain $\mathrm{pH}$ at 4.3. The hydroponic solution consisted of the following macronutrients in $\mathrm{mM}: \mathrm{MgCl}_{2}, 3.0 ;\left(\mathrm{NH}_{4}\right)_{2} \mathrm{SO}_{4}$, 0.25; $\mathrm{Ca}\left(\mathrm{NO}_{3}\right)_{2}, 1.0 \mathrm{M} ; \mathrm{KCl}, 2.0 ; \mathrm{CaCl}_{2}, 2.75 ; \mathrm{KH}_{2} \mathrm{PO}_{4}$, 0.18 ; and the following micronutrients in $\mu \mathrm{M}: \mathrm{H}_{3} \mathrm{BO}_{3}$, 50.0; $\mathrm{MnSO}_{4}, 10.0 ; \mathrm{CuSO}_{4}, 0.5 ; \mathrm{ZnSO}_{4}, 2.0 ; \mathrm{Na}_{2} \mathrm{MoO}_{4}$, $0.1 ; \mathrm{CoCl}_{2}, 0.1 ; 1 \%$ sucrose. Plants were grown in a growth chamber (Pervival, Model I-36LLVL) with $23{ }^{\circ} \mathrm{C}$ temperature, $65 \%$ humidity and light intensity of $100 \mu \mathrm{mol}$ photons $\mathrm{m}^{2} / \mathrm{s}$ by cool-white fluorescent tubes (GE) and 16-h photoperiod.

For evaluating $\mathrm{Al}$ sensitivity, seeds of the WT and individual mutant lines, i.e., nip1;2, almt1, almt1_mate and almt1_nip1;2, were germinated and grown in the above-mentioned hydroponic solution ( $\mathrm{pH} 4.3$ ) supplemented with $0,5,10,20,30,40$ or $50 \mu \mathrm{M}$ of $\mathrm{AlCl}_{3}$ for 7 days. Relative root growth (RRG\%) was calculated according to the following formula: RRG\% = root growth $(\mathrm{mm})$ of individual plants under $\mathrm{Al}$ treatment/mean root growth $(\mathrm{mm})$ under the control $(-\mathrm{Al})$ condition.

For phenotyping and genotyping the F2 individuals derived from the cross of almt1 and nip1;2, F2 seeds were germinated and grown in the hydroponic solution $(\mathrm{pH}$ 4.3) supplemented with $20 \mu \mathrm{M} \mathrm{AlCl} 3$ in Magenta boxes ( 120 seed in each box) for 7 days. Root length $(\mathrm{mm})$ of 215 randomly selected plants was measured before the plants were transferred to the soil for growth for 2 weeks. Then, DNAs were extracted from leaves of individual F2 plants. T-DNA insertions at the ALMT1 and NIP1;2 loci were evaluated by PCR followed the procedures mentioned above. Based on the genotypes at the ALMT1 and NIP1;2 loci, the F2 population could be classified into nine distinct genotypic combinations/ groups (Table 1; Additional file 1: Figure S3). Ten plants were randomly selected from each of the nine genotypic groups for calculation of the mean root growth $(\mathrm{mm})$ of the group (Table 1; Additional file 1: Figure S3). The root growth data were also used for performing Fisher's least significant difference (LSD) tests to distinguish statistically different phenotypic groups in the F2 population (Table 1; Additional file 1: Figure S3).

\section{RNA isolation and real-time RT-qPCR}

For gene expression analysis, $\sim 500$ seeds $(\sim 10 \mathrm{mg})$ were germinated in the above-mentioned control hydroponic solution (-Al) in a Magenta box for 6 days. Then, seedlings were transferred to a fresh hydroponic solution (pH 4.3) containing $20 \mu \mathrm{M} \mathrm{AlCl}$ and treated for $24 \mathrm{~h}$ before the root samples were collected. Three replicates (Magenta boxes) were included for each of the WT, nip1;2, almt1 and almt1_nip1;2 lines.

Total RNAs were extracted from the roots using an RNeasy Mini Kit (Qiagen) following the manufacturer's instructions. First-strand cDNA was synthesized in a reaction cocktail containing $1 \mathrm{X}$ reaction buffer, $5 \mu \mathrm{g}$ DNaseI-digested total RNA, $2.5 \mu \mathrm{M}$ of random oligos, 1 $\mathrm{mM}$ of each dNTP, $5 \mu \mathrm{L}$ of SuperScript III reverse transcriptase (Thermal Scientific, Inc.) in a total volume of $100 \mu \mathrm{L}$. The reaction was performed at $37^{\circ} \mathrm{C}$ for $90 \mathrm{~min}$, followed by heating at $72{ }^{\circ} \mathrm{C}$ for $10 \mathrm{~min}$. Subsequently, $2 \mu \mathrm{L}$ of RNase H (Thermal Scientific, Inc.) was added to each RT sample for 1.5 -h incubation at $37^{\circ} \mathrm{C}$. The synthesized samples were stored at $-20^{\circ} \mathrm{C}$ until use.

Real-time RT-qPCR was performed on a 7500 Fast Real-Time PCR System (Thermal Scientific, Inc.). Concentrations of each of cDNA samples were adjusted to $1 \mu \mathrm{g} /$ $\mu \mathrm{L}$. Each real-time PCR reaction contained $2 \mu \mathrm{L}$ of diluted cDNA sample, $10 \mu \mathrm{L}$ of $2 X$ Power SYBR Green PCR Master Mix (Thermal Scientific, Inc.), $0.15 \mu \mathrm{M}$ primer (forward and reverse each) in $20 \mu \mathrm{l}$ reaction volume. Three technical replicates were included for each cDNA sample. The real-time PCR cycling conditions were $95^{\circ} \mathrm{C}$ for 3 min; 39 cycles of $95^{\circ} \mathrm{C}$ for $10 \mathrm{~s}, 60^{\circ} \mathrm{C}$ for $30 \mathrm{~s}$, plate reading; 1 cycle of $65^{\circ} \mathrm{C}$ for $30 \mathrm{~s} ; 60$ cycles of $65^{\circ} \mathrm{C}$ for $5 \mathrm{~s}(+$ $0.5^{\circ} \mathrm{C} /$ cycle, ramp $0.5^{\circ} \mathrm{C} / \mathrm{sec}$ ), plate reading.

The sequences of optimal gene-specific real-time RTqPCR primers were NIP1;2, 5' - GGTTCGATATACTG ATAAGCCA-3' and 5'-GATACAACTTAACCTCCG ATGAC-3' (137 bp amplicon); ALMT1, 5'-TTCCCG ATTCCGAGCTCATT-3' (located in exon 5 and exon 6 junction) and 5'-CTCAGATTTTCAGATCCCAGTGGAC-3' (80 bp amplicon); $18 S$ rRNA (endogenous calibrator gene), 5' -CGCTATTGGAGCTGGAATTACC-3', 5' ${ }^{\prime}$-AATCCCTTAACGAGGATCCATTG-3' (71 bp amplicon). Gene structure, locations of the real-time PCR primers for corresponding genes were depicted (Additional file 1: Figure S5). In all real-time PCR amplifications mentioned below, a single peak of the dissociation curve was observed for each of the real-time RT-qPCR primer pairs, indicating that the primers were highly specific for the target genes. 
To construct standard curves for the NIP1;2, ALMT1 and $18 S$ rRNA amplifications, a serial dilutions (5x) of a cDNA sample $(1 \mu \mathrm{g} / \mu \mathrm{l})$ prepared from total WT RNA were prepared and subject to real-time PCR thermal cycling as mentioned above. Standard curves for the target genes (ALMT1 and NIP1;2) and the endogenous control gene (18S rRNA) were plotted as the log ng cDNA (six logs or dilutions included, three technical replicates for each dilution) vs. $\mathrm{C}_{\mathrm{T}}$ values of the corresponding samples. The equation for the standard curves was $y=m x+b$, where $y$ was $C_{T}$, $x$ was $\log$ ng of the cDNA sample, $m$ the slope of standard curve line and $b$ the $y$-intercept of the standard line. For the standard curves of the NIP1;2, ALMT1 and 18S rRNA amplification tested, $\mathrm{m}$ was $\sim-3.3$ and $R^{2}>0.99$, indicating high efficiency of the primers for PCR amplification.

Real-time qPCR samples for testing the expression of a known gene (i.e., ALMT1, NIP1;2 or $18 S$ rRNA) were put in a same 384-well plate together with the standard curve samples of the corresponding gene. The qPCR thermal cycling conditions were as mentioned above. The quantity of the real-time qPCR amplicons of the known gene were calculated for each sample based on its CT value and the standard curve of the corresponding known gene. Relative gene expression was calculated as the quantity of the target genes (i.e., $A L M T 1$ or NIP1;2) divided by the quantity of the $18 S$ rRNA gene of the same cDNA sample.

\section{Detection of organic acid exudation from roots}

Surface-sterilized seeds $(\sim 2-3 \mathrm{mg})$ from each line were germinated in Magenta boxes containing the sterile hydroponic growth solution ( $\mathrm{pH} 4.3)$ for 6 days, and then the seedlings were transferred to $20 \mathrm{ml}$ of filter-sterilized exudation solutions ( $\mathrm{pH} 4.3$ ) with or without $50 \mu \mathrm{M} \mathrm{Al}^{3+}$ in a sterile Petri dish for 2 days. The exudation solution consisted of the following macronutrients in $\mu \mathrm{M}: \mathrm{MgCl}_{2}, 275 ; \mathrm{CaCl}_{2}, 275 ; \mathrm{KCl}$, 275; $\mathrm{Ca}\left(\mathrm{NO}_{3}\right)_{2}, 33.4 ; \mathrm{MgSO}_{4}, 33.4 ; \mathrm{K}_{2} \mathrm{SO}_{4}, 16.7$; and the following micronutrients in $\mu \mathrm{M}: \mathrm{H}_{3} \mathrm{BO}_{3}, 50.0 ; \mathrm{MnSO}_{4}, 10.0$; $\mathrm{CuSO}_{4}, 0.5 ; \mathrm{ZnSO}_{4}, 2.0 ; \mathrm{Na}_{2} \mathrm{MoO}_{4}, 0.1 ; \mathrm{CoCl}_{2}, 0.1$; and $1 \%$ sucrose, supplemented with $3.0 \mathrm{mM}$ Homo-PIPES (pH 4.3). Then, the exudation solutions were collected and the numbers of plants were counted. To remove $\mathrm{Al}^{3+}$ and other inorganic anions, the exudation solutions were treated with anionic and cationic chromatography columns. Subsequently, the eluate was concentrated to dryness using a rotary evaporator at $40^{\circ} \mathrm{C}$. The residue was re-dissolved in 1 $\mathrm{ml}$ of Milli-Q water. Malate and citrate concentrations were then measured according to the enzymatic method previously described [22].

\section{Root cell sap and cell wall preparation and Al determination}

Arabidopsis lines were firstly germinated and grown in the hydroponic solution ( $\mathrm{pH} 4.3$ ) for 7 days, then treated in a fresh hydroponic solution ( $\mathrm{pH}$ 4.3) supplemented with $50 \mu \mathrm{M} \mathrm{AlCl}_{3}$ for $2 \mathrm{~d}$. After the treatment, the roots were cut and washed three times with deionized water. The cut root samples were centrifuged at $3000 \mathrm{rpm}$ for $10 \mathrm{~min}$ at $4{ }^{\circ} \mathrm{C}$ in an Ultra free-MC Centrifugal filter unit (Millipore) to remove the apoplastic solution, and frozen in $\mathrm{a}-80^{\circ} \mathrm{C}$ freezer overnight. The frozen root samples were de-frozen at room temperature, and then centrifuging at $13,000 \mathrm{rpm}$ for $10 \mathrm{~min}$ to separate the root cell sap solution from the residual cell wall. The cell wall sample was washed with $70 \%$ ethanol three times and then digested in $1 \mathrm{~mL}$ of $2 \mathrm{M} \mathrm{HCl}$ for at least $24 \mathrm{~h}$ with gentle shaking. $\mathrm{Al}$ contents in the symplastic solution and cell wall extract were determined by inductively coupled plasma mass spectrometry (ICP-MS).

For testing the effects of sequential $\mathrm{Al}^{3+}$ and malate treatment on $\mathrm{Al}$ accumulation, 150 7-d-old seedlings of the WT, almt1, nip1;2-3 and almt1_nip1;2 lines were pretreated with the hydroponic solution ( $\mathrm{pH} 4.3$ ) supplemented with $50 \mu \mathrm{M} \mathrm{AlCl}$ for $8 \mathrm{~h}$. The samples were then washed three times with $0.5 \mathrm{mM} \mathrm{CaCl}_{2}$ and treated in hydroponic solutions $(\mathrm{pH} 4.3)$ supplemented with or without $200 \mu \mathrm{M}$ malate for $8 \mathrm{~h}$. Aluminum concentrations in cell sap and cell wall were measured as mentioned above. Three biological replicates (Magenta boxes) with the same setting were prepared for each plant line and each treatment.

\section{Supplementary information}

Supplementary information accompanies this paper at https://doi.org/10. 1186/s12870-020-02338-y.

Additional file 1 Figure S1. Seeds of WT and nip 1;2-1, nip 1;2-2 and nip 1;2-3 mutants were germinated and grown in hydroponic solution (pH 4.3) supplemented with $20 \mu \mathrm{M}$ of $\mathrm{AlCl}_{3}$ for 5 days. Figure S2. Seeds of WT, almt1, mate, nip 1;2 and almt1_mate, almt1_nip 1;2 double mutants were germinated and grown in hydroponic solution $(\mathrm{pH} 4.3)$ supplemented without (-Al) or with (+Al) $20 \mu \mathrm{M}$ of $\mathrm{AlCl}_{3}$ for 5 days. Figure S3. Root growth of different genotypes of the F2 population. Figure S4. Gene structure, positions of T-DNA insertions and PCR primers of ALMT1 and NIP1;2. Figure S5. Gene structure, position and size of realtime RT-PCR amplicon for ALMT1, NIP1;2 and 18S rRNA.

\section{Abbreviations \\ Al-Mal: Aluminum-malate; ALMT: Al-activated malate transporter; \\ KO: Knockout; MATE: Multidrug and toxic compound extrusion; NIP: Nodulin 26-like intrinsic protein; RRG: Relative root growth}

\section{Acknowledgments}

We thank S. K. Giri for technical assistance for ICP-MS analyses.

\section{Author's contributions}

J.L. conceived and supervised the research. Y.W. and J.L. designed the experiments. Y.W., W.Y., Y. Cao, Y. Cai, S.M.L., W.W., Y.K. and C.L. performed the experiments and analyzed the results. J.L. and Y.W. wrote the paper. All authors have read and approved the final manuscript.

\section{Funding}

This work was supported by a grant from the National Natural Science Foundation of China (41877423) to Y.W. and a USDA-ARS CRIS fund (190721000-034-00D) to J.L. 


\section{Availability of data and materials}

The datasets used and analyzed during the current study are available from the corresponding author on reasonable request.

\section{Ethics approval and consent to participate}

Not applicable.

\section{Consent for publication}

Not applicable.

\section{Competing interests}

The authors declare that they have no competing interests.

\section{Author details}

'Key Laboratory for Water Quality and Conservation of the Pearl River Delta Ministry of Education, School of Environmental Science and Engineering, Guangzhou University, Guangzhou 510006, Guangdong, China. ${ }^{2}$ Robert Holley Center, US Department of Agriculture, Agricultural Research Service, Cornell University, Ithaca, NY 14853, USA. ${ }^{3}$ Medical Plant Laboratory, Tianjin Research Center of Agricultural Biotechnology, Tianjin 300384, China. ${ }^{4}$ College of Natural Resources and Environment, South China Agricultural University, Guangzhou 510642, Guangdong, China. ${ }^{5}$ School of Life Sciences, Inner Mongolia University, Hohhot 010021, Inner Mongolia, China.

Received: 23 September 2019 Accepted: 11 March 2020

Published online: 18 March 2020

\section{References}

1. Kochian LV, Hoekenga OA, Pineros MA. How do crop plants tolerate acid soils? Mechanisms of aluminum tolerance and phosphorous efficiency. Annu Rev Plant Biol. 2004;55:459-93.

2. Zhang $X$, Long $Y$, Huang J, Xia J. Molecular mechanisms for coping with Al toxicity in plants. Int J Mol Sci. 2019;20:1551.

3. Rout G, Samantaray S, Das P. Aluminium toxicity in plants: a review. Agronomie. 2001;21:3-21.

4. Matsumoto H. Cell biology of aluminum toxicity and tolerance in higher plants. Int Rev Cytol. 2000;200:1-46.

5. Ryan PR, Ditomaso JM, Kochian LV. Aluminium toxicity in roots: an investigation of spatial sensitivity and the role of the root cap. J Exp Bot. 1993:44:437-46

6. McQueen-Mason S, Rochange F. Expansins in plant growth and development: an update on an emerging topic. Plant Biol. 1999;1:19-25.

7. Voesenek L, Benschop J, Bou J, Cox M, Groeneveld H, Millenaar F, Vreeburg $\mathrm{R}$, Peeters A. Interactions between plant hormones regulate submergenceinduced shoot elongation in the flooding-tolerant dicot Rumex palustris. Ann Bot. 2003;91:205-11.

8. Gunse B, Poschenrieder C, Barcelo J. Water transport properties of roots and root cortical cells in proton-and Al-stressed maize varieties. Plant Physiol. 1997;113:595-602.

9. Ma JF, Shen R, Nagao S, Tanimoto E. Aluminum targets elongating cells by reducing cell wall extensibility in wheat roots. Plant Cell Physiol. 2004;45: 583-9.

10. Tabuchi A, Matsumoto H. Changes in cell-wall properties of wheat (Triticum aestivum) roots during aluminum-induced growth inhibition. Physiol Plantarum. 2001;112:353-8.

11. Horst WJ. The role of the apoplast in aluminium toxicity and resistance of higher plants: a review. Z Pflanzenernähr Bodenkd. 1995;158:419-28.

12. Horst WJ, Wang Y, Eticha D. The role of the root apoplast in aluminiuminduced inhibition of root elongation and in aluminium resistance of plants: a review. Ann Bot. 2010;106:185-97.

13. Yang Z-B, Geng X, He C, Zhang F, Wang R, Horst WJ, Ding Z. TAA1regulated local auxin biosynthesis in the root-apex transition zone mediates the aluminum-induced inhibition of root growth in Arabidopsis. Plant Cell. 2014;26:2889-904.

14. Liu J, Piñeros MA, Kochian LV. The role of aluminum sensing and signaling in plant aluminum resistance. J Integr Plant Biol. 2014;56:221-30.

15. Kochian LV, Piñeros M, Liu J, Magalhaes J. Plant adaptation to acid soils: the molecular basis for crop aluminum resistance. Annu Rev Plant Biol. 2015;66: 23-8.

16. Ma JF, Ryan PR, Delhaize E. Aluminium tolerance in plants and the complexing role of organic acids. Trends Plant Sci. 2001;6:273-8.
17. Tolrà R, Barceló J, Poschenrieder C. Constitutive and aluminium-induced patterns of phenolic compounds in two maize varieties differing in aluminium tolerance. J Inorg Biochem. 2009;103:1486-90.

18. Pellet DM, Papernik LA, Kochian LV. Multiple aluminum-resistance mechanisms in wheat (roles of root apical phosphate and malate exudation). Plant Physiol. 1996;112:591-7.

19. Wang Y, Li R, Li D, Jia X, Zhou D, Li J, Lyi SM, Hou S, Huang Y, Kochian LV, Liu J. NIP1;2 is a plasma membrane-localized transporter mediating aluminum uptake, translocation, and tolerance in Arabidopsis. Proc Natl Acad Sci U S A. 2017;114(19):5047-52.

20. Qiu W, Wang N, Dai J, Wang T, Kochian LV, Liu J, Zuo Y. AhFRDL1 mediated citrate secretion contributes to adaptation of peanuts for Fe deficiency and Al stress. J Exp Bot. 2019;70:2873-86.

21. Melo JO, Lana UG, Piñeros MA, Alves V, Guimarães $C T$, Liu J, Zheng $Y$, Zhong S, Fei Z, Maron LG. Incomplete transfer of accessory loci influencing SbMATE expression underlies genetic background effects for aluminum tolerance in sorghum. Plant J. 2013;73:276-88.

22. Delhaize E, Ryan PR, Randall PJ. Aluminum tolerance in wheat (Triticum aestivum L.)(II. Aluminum-stimulated excretion of malic acid from root apices). Plant Physiol. 1993;103:695-702.

23. Furukawa J, Yamaji N, Wang H, Mitani N, Murata Y, Sato K, Katsuhara M, Takeda K, Ma JF. An aluminum-activated citrate transporter in barley. Plant Cell Physiol. 2007:48:1081-91.

24. Hoekenga OA, Maron LG, Piñeros MA, Cançado GM, Shaff J, Kobayashi Y, Ryan PR, Dong B, Delhaize E, Sasaki T. AtALMT1, which encodes a malate transporter, is identified as one of several genes critical for aluminum tolerance in Arabidopsis. Proc Natl Acad Sci U S A. 2006;103:9738-43.

25. Liu J, Magalhaes JV, Shaff J, Kochian LV. Aluminum-activated citrate and malate transporters from the MATE and ALMT families function independently to confer Arabidopsis aluminum tolerance. Plant J. 2009;57: 389-99.

26. Liu J, Luo X, Shaff J, Liang C, Jia X, Li Z, Magalhaes J, Kochian LV. A promoter-swap strategy between the AtALMT and AtMATE genes increased Arabidopsis aluminum resistance and improved carbon-use efficiency for aluminum resistance. Plant J. 2012;71:327-37.

27. Magalhaes JV, Liu J, Guimaraes CT, Lana UG, Alves VM, Wang Y-H, Schaffert RE, Hoekenga OA, Pineros MA, Shaff JE. A gene in the multidrug and toxic compound extrusion (MATE) family confers aluminum tolerance in sorghum. Nat Genet. 2007;39:1156-61.

28. Sasaki T, Yamamoto Y, Ezaki B, Katsuhara M, Ahn SJ, Ryan PR, Delhaize E, Matsumoto $\mathrm{H}$. A wheat gene encoding an aluminum-activated malate transporter. Plant J. 2004;37:645-53.

29. Zhao Z, Gao X, Ke Y, Chang M, Xie L, Li X, Gu M, Liu J, Tang X. A unique aluminum resistance mechanism conferred by aluminum and salicylic-acidactivated root efflux of benzoxazinoids in maize. Plant Soil. 2019:437:273-89.

30. Delhaize $E$, Gruber BD, Ryan PR. The roles of organic anion permeases in aluminium resistance and mineral nutrition. FEBS Lett. 2007;581:2255-62.

31. Ma JF, Hiradate $\mathrm{S}$, Matsumoto $\mathrm{H}$. High aluminum resistance in buckwheat II. Oxalic acid detoxifies aluminum internally. Plant Physiol. 1998;117:753-9.

32. Ma JF, Hiradate S, Nomoto K, Iwashita T, Matsumoto H. Internal detoxification mechanism of $\mathrm{Al}$ in hydrangea (identification of $\mathrm{Al}$ form in the leaves). Plant Physiol. 1997;113:1033-9.

33. luchi S, Koyama H, luchi A, Kobayashi Y, Kitabayashi S, Kobayashi Y, Ikka T, Hirayama T, Shinozaki K, Kobayashi M. Zinc finger protein STOP1 is critical for proton tolerance in Arabidopsis and coregulates a key gene in aluminum tolerance. Proc Natl Acad Sci U S A. 2007;104:9900-5.

34. Jiang F, Wang T, Wang Y, Kochian LV, Chen F, Liu J. Identification and characterization of suppressor mutants of stop1. BMC Plant Biol. 2017;17:128.

35. Wang Y, Cai Y, Cao Y, Liu J. Aluminum-activated root malate and citrate exudation is independent of NIP1;2-facilitated root-cell-wall aluminum removal in Arabidopsis. Plant Signal Behav. 2018;13:e1422469.

36. Cordell HJ. Epistasis: what it means, what it doesn't mean, and statistical methods to detect it in humans. Human Mol Genet. 2002;11:2463-8.

37. Phillips PC. Epistasis - the essential role of gene interactions in the structure and evolution of genetic systems. Nat Rev Genet. 2008;9:855.

38. Shen R, Ma JF. Distribution and mobility of aluminium in an Alaccumulating plant, Fagopyrum esculentum Moench. J Exp Bot. 2001;52: $1683-7$.

39. Shen R, Ma J, Kyo M, Iwashita T. Compartmentation of aluminium in leaves of an Al-accumulator, Fagopyrum esculentum Moench. Planta. 2002;215: 394-8. 
40. Ma JF. Syndrome of aluminum toxicity and diversity of aluminum resistance in higher plants. Int Rev Cytol. 2007;264:225-52.

41. Sivaguru M, Horst WJ. The distal part of the transition zone is the most aluminum-sensitive apical root zone of maize. Plant Physiol. 1998;116:15563.

42. Sivaguru M, Liu J, Kochian LV. Targeted expression of SbMATE in the root distal transition zone is responsible for sorghum aluminum resistance. Plant J. 2013;76:297-307.

43. Zheng SJ, Ma JF, Matsumoto H. High aluminum resistance in buckwheat I. Al-induced specific secretion of oxalic acid from root tips. Plant Physiol. 1998;117:745-51.

\section{Publisher's Note}

Springer Nature remains neutral with regard to jurisdictional claims in published maps and institutional affiliations.

Ready to submit your research? Choose BMC and benefit from:

- fast, convenient online submission

- thorough peer review by experienced researchers in your field

- rapid publication on acceptance

- support for research data, including large and complex data types

- gold Open Access which fosters wider collaboration and increased citations

- maximum visibility for your research: over $100 \mathrm{M}$ website views per year

At BMC, research is always in progress.

Learn more biomedcentral.com/submissions 